\section{Histochemical and biometric study of the gastrointestinal system of Hyla orientalis (Bedriaga, 1890) (Anura, Hylidae)}

\section{E. Akat, H. Arıkan, B. Göçmen \\ Department of Biology, Zoology Section, Faculty of Science, Ege University, Bornova-Izmir, Turkey}

\section{Abstract}

This study was carried out to assess the localization of hyaluronic acid (HA) and the distribution of glycoproteins in the gastrointestinal system of adult Hyla orientalis. Histochemical analysis of the gastrointestinal system in $H$. orientalis showed that mucous content included glycogene and/or oxidable dioles [periodic acid/Schiff (PAS)+], neutral or acid-rich (PAS/AB pH 2.5+), sialic acid residues $(\mathrm{KOH} / \mathrm{PAS}+)$ and acid sulphate [Aldehyde fuchsin (AF)+] glycoproteins. However the mucus content was not the same in stomach, small and large intestine. The mucus content of stomach included only glycogene and/or oxidable dioles and sialic acid residues. Besides these histochemical methods, the localization of HA was detected using biotinylated hyaluronic acid binding protein labeled with streptavidin-fluorescein isothiocyanate (FITC). In the extracellular matrix of the submucosa, the reaction for HA was evident. Since HA was located in submucosa beneath the epithelial layer of gastrointestinal system, it has a significant role in hydric balance, and essential to provide the gastrointestinal system integrity and functionality. According to biometric results, there were statistical differences between small and large intestine in terms of the amount of material stained positive with $\mathrm{PAS} / \mathrm{AB}, \mathrm{PAS}, \mathrm{KOH} / \mathrm{PAS}$ and AF/AB. Additionally, number of goblet cells in the small and large intestine was significantly different.

\section{Introduction}

The gastrointestinal system is one of the most metabolically active system and prominent at all life stages due to energy utilisation and perform digestion of the food, nutrient absorption and expelling waste products. ${ }^{1,2}$ The occurrence of mucus is a common feature in digestive tract. ${ }^{3}$ Mucus consists of approximately $95 \%$ water and $5 \%$ mucins. ${ }^{4}$ Mucins are high molecular weight glycoproteins produced by epithelial tissues. ${ }^{5}$

In vertebrates, glycoconjugates on the cell surface and in extracellular matrix exhibit many important functions including cell-cell and cell-matrix adhesion events, cell signaling and control of cell membrane permeability. ${ }^{6-8}$ Hyaluronic acid (HA) is a dominant part of the matrix glycosaminoglycans in higher vertebrates. Although HA formerly known as a passive molecule, in recent years researchers have reported the new roles of HA such as promoting cell motility, regulating cell-cell and cell-matrix adhesion, proliferation, embryological development, repair and regeneration, cell interaction in cancer and vascular diseases. ${ }^{9-13}$

Amphibians have significant role as a study model in physiology, and this group is a standard model for the study of many biological processes. ${ }^{14}$ However relatively few studies have been carried out on amphibian gastrointestinal tract. There are some reports investigating the gastrointestinal epithelial transformation from the larval to adult type and apoptosis. ${ }^{15,16}$ Additionally, histological and histochemical changes in digestive tract of Ceratophrys ornata and Xenopus laevis during metamorphic climax were reported. ${ }^{17,18}$ In general, studies related to digestive system were carried out on reptiles, birds and mammals. But the cell renewal system of adult epithelium in the amphibian stomach is similar to mammalian stomach, where cell proliferation is localized in the neck region of gastric glands. Therefore, the amphibian digestive tract serves as a model system for studying mammalian organ regeneration. ${ }^{19-22}$

The globally distributed Hylidae is one of the largest families of anurans comprising of more than 940 known species and 51 genera. The tree frog genus Hyla consists of 37 species found in North America, Central America, Europe and Asia. ${ }^{23,24}$ The eastern tree frog Hyla orientalis is a small arboreal species. It goes to water only in the breeding season, preferring clean, deep, heavily-vegetated water. ${ }^{25} \mathrm{H}$. orientalis was previously not distinguished from H. arborea (Linnaeus, 1758), but south-eastern European and western Anatolian $H$. arborea populations were considered a separate species. ${ }^{26} H$. orientalis (formerly $H$. arborea) is carnivore and has a broad dietary diversity which was expected as a consequence of exploiting the habitat both vertically and horizontally, possibly allowing access to a broader spectrum prey. ${ }^{27}$ In addition, this species are easily captured and transported, easily maintained in the laboratory.

The aim of the current study was to analyze biometric and histochemical characterization, and the determination of $\mathrm{HA}$ in gastrointestinal system for a better understanding of the role of $\mathrm{HA}$.
Correspondence: Dr. Esra Akat, Department of Biology, Zoology Section, Faculty of Science, Ege University, 35100 Bornova-Izmir, Turkey. Tel.+90.23.23112404 - Fax: +90.23.23881036.

E-mail: esra.akat@ege.edu.tr

Key words: Gastrointestinal system, goblet cell, glycoproteins, hyaluronic acid, amphibian, Hyla.

Acknowledgments: the authors thank Paul Bollyky for supplying B-HABP and for his invaluable help about immunohistochemistry. Thanks also to Yücel Akgül for his valuable advices on immunohistochemistry.

Received for publication: 25 September 2014. Accepted for publication: 6 November 2014.

This work is licensed under a Creative Commons Attribution NonCommercial 3.0 License (CC BYNC 3.0).

(C) Copyright E. Akat et al., 2014

Licensee PAGEPress, Italy

European Journal of Histochemistry 2014; $58: 2452$ doi:10.4081/ejh.2014.2452

\section{Materials and Methods}

\section{Histochemistry}

The present study was carried out according to the Animal Ethical Committee of Ege University, Faculty of Medicine and approved by the Republic of Turkey Ministry of Forestry and Water Affairs (date: 24 January 2014, permit no: 72784983-488.04-20643). Eight specimens (four adult males and four adult females) of $H$. orientalis were captured from Menderes-Izmir, Turkey (N $38^{\circ} 15^{\prime}$ and E $27^{\circ} 8^{\prime}$ ) in April. After $48 \mathrm{~h}$, animals were anaesthetized with ether, and euthanized by decapitation, and immediately afterwards the gastrointestinal systems were removed. Gastrointestinal tissue samples were fixed in $4 \%$ paraformaldehyde overnight at $4^{\circ} \mathrm{C}$. Thereafter, the tissue samples were rinsed with $0.1 \mathrm{M}$ phosphate-buffered saline (PBS), $\mathrm{pH} 7.2$, and processed according to the standard histological protocols for paraffin embedding. Five-micrometer-thick sections were stained with Gill's hematoxylin-eosin (HE) to demonstrate the general morphology of the tissue. Histochemical techniques [Periodic acid/Schiff (PAS), PAS/Alcian Blue (AB) $\mathrm{pH}$ 2.5, KOH/PAS, Aldehyde fuchsin (AF) and $\mathrm{AF} / \mathrm{AB} \mathrm{pH} 2.5$ ] were performed for the identification of glycoproteins.

The localization of HA was detected using biotinylated hyaluronic acid binding protein (B-HABP) (Benaroya Research Inst., Seattle, WA, USA). Sections were deparaffinized, and non-specific binding sites were blocked with 
$2 \%$ bovine serum albumin (BSA) in PBS, $\mathrm{pH}$ 7.2 , and then incubated in B-HABP overnight at $4^{\circ} \mathrm{C}$. After application of B-HABP which labeled with streptavidin-fluorescein isothiocyanate (FITC) (Sigma Chemical Co., St. Louis, M0, USA). All washes were performed using PBS. For negative control hyaluronidase digested sections were used. The specificity of the staining was controlled by digesting some of sections with Streptomyces hyaluronidase prior to the incubation with the probe. For positive control, sections were stained with BHABP/HA. Sections were photographed using a Leica DM3000 microscope (Leica Microsystems, Wetzlar, Germany) that was equipped with a Leica digital camera (DFC290).

\section{Biometric analyses}

Image $\mathrm{J}$ programme was used to calculate the number of goblet cells per unit of epithelial area $\left(\mathrm{mm}^{2}\right)$. Biometric analyses were evaluated by measuring the amount of material stained positive with $\mathrm{PAS} / \mathrm{AB}, \mathrm{PAS}, \mathrm{KOH} / \mathrm{PAS}$ and $\mathrm{AF} / \mathrm{AB}$ in small and large intestine in each frog. These measurements were taken directly from the sections using micrometric ocular. On each animal; the lengths (L) and widths (W) of one hundred randomly chosen goblet cells in ileum and large intestine were measured. The areas of positive staining cell $\left(\mu \mathrm{m}^{2}\right)$ were calculated as $\mathrm{LW} \pi / 4 .^{28}$ The differences were compared by 2 -tailed $t$-test using SPSS 16.0. We set the significance level at $P \leq 0.05$.

\section{Results}

The gastrointestinal system of $H$. orientalis was composed of the typical layers as seen in higher vertebrates; mucosa, submucosa, muscularis externa and serosa (Figure 1A). The stomach of $H$. orientalis was subdivided into a wide corpus or fundus containing gastric glands and a short pyloric portion. The stomach was covered by serosa which was lined with a simple flat epithelium. The muscularis externa was composed of a thick layer of smooth muscle fibers. The submucosa was formed of loose connective tissue rich in blood vessels. The gastric mucosa was lined through its length by mucous secreting epithelial columnar cells with folds. Many gastric pits formed as a result of the mucosal layer into the lamina propria where gastric glands were located. The gastric glands were mostly of a simple tubular type. The gastric gland cells and apical portion of mucous cells showed PAS positive reaction (Figure $1 \mathrm{~A}, \mathrm{E}$ ) but did not react with $\mathrm{AB}$ and $\mathrm{AF}$.

The mucosa of the small intestine was thrown into large numbers of high narrow lon- gitudinal folds called intestinal villi. The mucosal epithelium of the small intestine was composed of two kinds of cells; absorptive cells and goblet cells (Figure 1F). The mucosal epithelium of the small intestine showed complete absence of the intestinal glands and glandular crypts. The mucosal epithelium of the large intestine had fewer and shorter folds
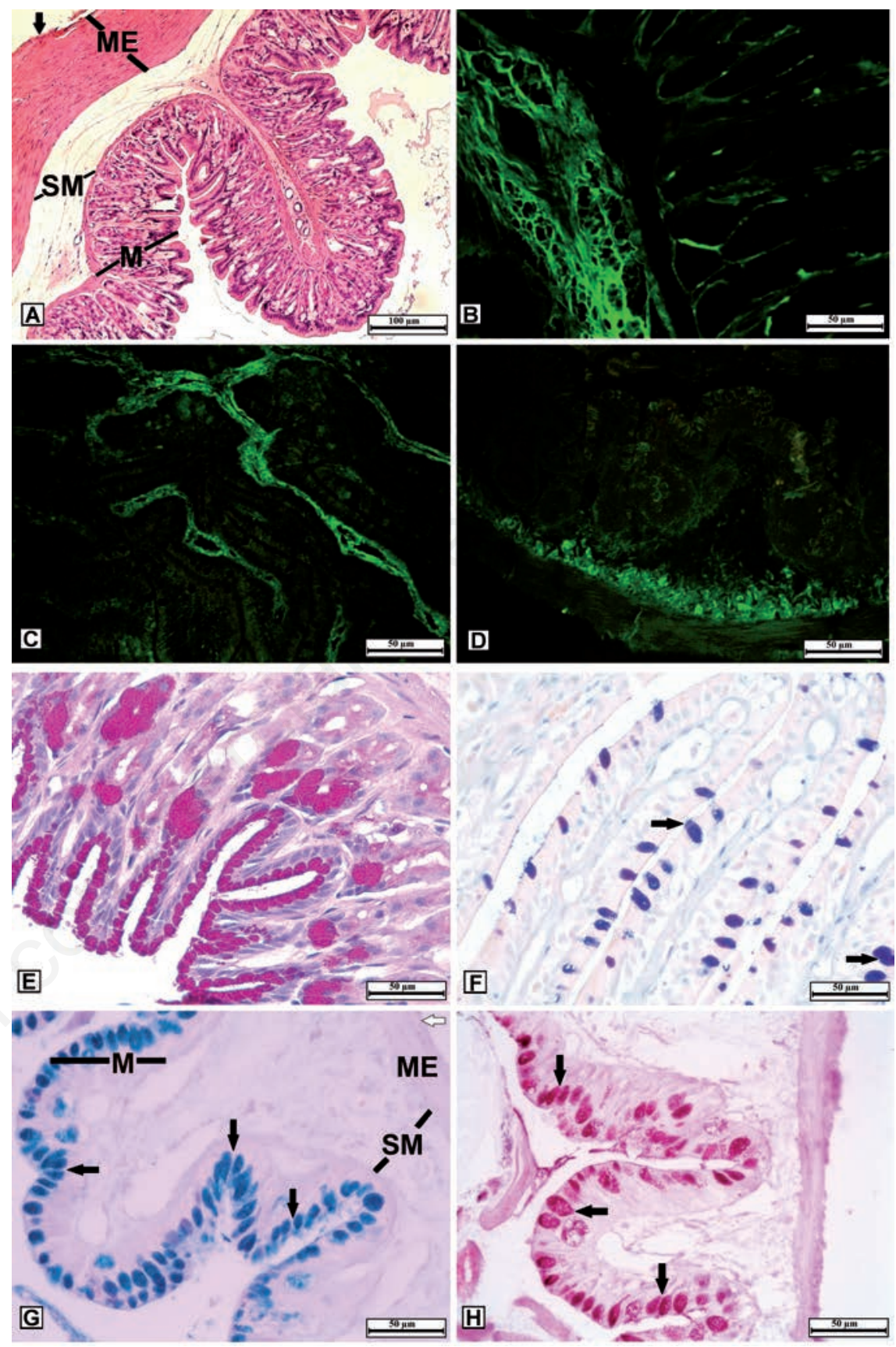

Figure 1. A-D) Histological examination and immunofluorescence localization of Hyaluronic acid (HA) in the gastrointestinal system in $H$. orientalis. A) Layers of the stomach; M, mucosa; SM, submucosa; ME, Muscularis externa; black arrow, serosa. B) Stomach section. C) Small intestine section. D) Large intestine section; the localization of HA mainly in submucosa to maintain gastrointestinal system integrity and functionality. E-H) Histochemical evaluation of glycoproteins (GPs) in the gastrointestinal system of $H$. orientalis. E) Reacted positively to PÁS in gastric gland cells and the apical portion of mucous cells. F) Strong sulphated GPs in goblet cells, AF/AB pH 2.5 (AB dominant). G) Neutral and/or acid rich GPs in goblet cells of large intestine; M, mucosa; SM, submucosa; ME, Muscularis externa; white arrow, serosa; PAS/AB pH 2.5 (AB dominant) H) GPs with sialic acid residues in goblet cells; KOH/PAS, goblet cells (black arrow). 
containing simple columnar cells and numerous goblet cells. Glandular crypts were not observed in the mucosa of large intestine (Figure 1G). In both small and large intestine, the submucosa was formed of loose connective tissue containing a number of blood vessels. The next layer was the muscularis externa layer, composed of layers of smooth muscle. The outermost layer was the serosal layer, composed of a thin layer of epithelial tissue (Figure 1G).

By means of histochemical techniques the intestinal goblet cells with positive PAS reaction indicated that these cells produced mucus contains GPs with oxidizable vicinal diols and/or glycogen. The content of large intestine goblet cells showed positive reaction with PAS/AB pH 2.5 (AB dominant) (Figure 1G). The histochemical method (KOH/PAS) revealed the histochemical properties of mucous cells contained sialic acid residues in large intestine (Figure 1H). After aldehydefuchsin/alcian blue (AF/AB) staining method, the secretory contents of the mucous cells in both small (Figure 1F) and large intestine had a strong affinity to $A B$ due to dominance of acidic glycoproteins. However, AF staining method showed that goblet cells of both small and large intestine also included GPs with sulphate.

Demonstration of HA immunoreactivity was carried out using an FITC labeled specific probe (B-HABP) in paraffinized sections by fluorescent microscopy. This reaction occurred with HA dispersed through the extracellular matrix. HA immunoreactivity indicated that it was located in submucosa beneath the epithelial layer of the gastrointestinal system. However, the HA immunoreactivity was not observed in smooth muscle of the gastrointestinal system (Figure 1 B,C,D).

According to our results, there were statistical differences between small and large intestine in terms of the amount of material stained positive with PAS/AB, PAS, KOH/PAS and AF/AB (Table 1). Additionally, number of goblet cells in the small and large intestine was significantly different (Table 2).

\section{Discussion}

This is the first study that the demonstrate the HA presence in amphibian gastrointestinal tract. Histochemical methods proved to characterize the content of mucous cells which had neutral, acidic glycoproteins, glycoproteins with sialic acids and sulphated glycoproteins. The HA immunoreactivity was located in the submucosa beneath the epithelial layer of the gastrointestinal system.

Amphibian digestive tract is highly respon- sive and sensitive to environmental cues. ${ }^{29}$ Although, amphibians are a standard and classic model organism for the study of many physiological processes and serves as a good model system for studying organ regeneration of the digestive tract common to terrestrial vertebrates, there are a few reports related to amphibian digestive system. In recent years, some physiological studies were carried out for the effect of arousal and re-feeding on digestive tract morphology following aestivation or food restriction. In rats re-fed ad libitum after 11 days of total food restriction, small intestine mass increased by up to $75 \%$ within $24 \mathrm{~h}$ and by $200 \%$ within 3 days of re-feeding. ${ }^{30}$ In the amphibians Bufo alvarius, Ceratophrys ornata and Pyxicephalus adspersus, re-feeding following 1 month of food deprivation during aestivation, resulted in an average increased in intestinal wet mass of over $200 \% .{ }^{31}$ Another study reported that the mass of the small intestine of burrowing frog Cyclorana alboguttata increased by over $450 \%$ within $36 \mathrm{~h}$ of re-feeding following 3 months of aestivation. Data from these studies and similar studies have demonstrated that the gastrointestinal tract of frogs is highly plastic and responds to variations in food availability both rapidly and highly reversibly. ${ }^{32}$

According to our results, the gastric mucin did not show $\mathrm{AB}$ or $\mathrm{AF}$ positive reaction, but reacted positively to PAS in gastric gland cells and the apical portion of mucous cells due to presence of neutral GPs. The same results were observed in some amphibians Triturus carnifex ${ }^{33}$ Bufo viridis ${ }^{34}$ and in some reptiles. ${ }^{35-37}$ However, mucous cells of stomach in Rana a. aurora, ${ }^{38}$ some species of reptiles, ${ }^{39}$ many mammals ${ }^{40}$ and some species of fish ${ }^{41}$ produce neutral and acid mucins. Neutral GPs protect against mechanical injuries, pathogens and aggressive pepsin. ${ }^{38}$ Additionally this type of mucin was poor in anions. This may prevent hydrogen ions and water molecules in the gastric juice being drawn into the protective mucus layer. ${ }^{42}$ Based on this, because of stomach extract containing a high concentration of hydrogen ions, neutral GPs probably behave like a proton pump.

In $H$. orientalis the mucosa of intestine consisted of a single layer of columnar epithelial cells with goblet cells. There were statistical differences between small and large intestine in terms of the number of goblet cells. The increased density of goblet cells towards to the large intestine observed in this study. This situation probably related to an increased need of lubrication for the ejection of feces, and has been presented in some studies on vertebrate gastrointestinal tract. ${ }^{33,43-45}$ The content of goblet cells in small and large intestine showed positive reaction with $\mathrm{PAS} / \mathrm{AB} \mathrm{pH} 2.5$ (AB dominant). The $A B$ sequence revealed acidic GPs that could be responsible for an increasing viscosity of the secretions. ${ }^{46}$ Additionally, acidic GPs have been proposed to protect the intestinal epithelium against the degradative actions of glycosidases. ${ }^{47} \mathrm{AF} / \mathrm{AB} \mathrm{pH} 2.5$ and $\mathrm{AF}$ staining methods showed that the goblet cells of $H$. orientalis contained acidic and sulphated

Table 1. Mean, standard deviation, $t$-value and significance of the measured staining area $\left(\mu \mathrm{m}^{2}\right)$.

\begin{tabular}{ccccc} 
& Mean & SD & $t$-value & Sig. (2-tailed) \\
PAS/AB staining & & & & \\
Small intestine & 83.29 & 23.32 & 6.26 & $<0.05^{*}$ \\
Large intestine & 118.07 & 29.54 & 6.26 & $<0.05^{*}$ \\
KOH/PAS staining & & & & \\
Small intestine & 77.08 & 27.98 & 6.50 & $<0.05^{*}$ \\
Large intestine & 115.07 & 28.48 & 6.50 & $<0.05^{*}$ \\
\hline PAS staining & & & & \\
Small intestine & 80.75 & 22.10 & 14.65 & $<0.05^{*}$ \\
Large intestine & 123.60 & 36.73 & 14.65 & $<0.05^{*}$ \\
AF/AB staining & & & & \\
Small intestine & 85.31 & 25.57 & 6.12 & $<0.05^{*}$ \\
Large intestine & 124.66 & 36.94 & 6.12 & $<0.05^{*}$ \\
\hline
\end{tabular}

Table 2. Comparison of mean goblet cell numbers between small and large intestine.

\begin{tabular}{lcccc} 
Goblet cell $\left(\times 10^{3}\right) / \mathrm{mm}^{2}$ & Mean & SD & $t$-value & Sig. (2-tailed) \\
Small intestine & 0.85 & 0.07 & -8.45 & $<0.05^{*}$ \\
Large intestine & 2.3 & 0.14 & -8.45 & $<0.05^{*}$ \\
\hline
\end{tabular}

*Significant at Student's t-test, $\mathrm{P} \leq 0.05$. 
glycoproteins. In this study most goblet cells showed $A B$ positive material dominance like in most goblet cells of $P$. antalyae. ${ }^{48}$ The presence of a large number of microorganisms is usually associated with the secretion of sulphated mucins. ${ }^{34}$ Sulphated GPs are abundant in goblet cells of intestinal tracts, where protein digestion and trapping of bacteria (or other pathogens) occur, and may have a role in the stimulation of immunity there. ${ }^{43,49} \mathrm{KOH} / \mathrm{PAS}$ staining method revealed the presence of sialic acid residues. Sialic acid residues and sulphated glycoproteins increase the secretion viscosity to play the main role of protection. ${ }^{50}$ Additionally sialic acid residues together with sulphated groups cause the negative charge of the GPs and mask receptor sites for pathogen forms as bacteria, viruses and mycoplasma species. ${ }^{33,51}$ To observe the effects of bacteria on intestinal goblet cell mucin production during post-hatch development, differences in the small intestine of conventionally reared and low bacterial load broiler chicks were examined. Mucin composition was influenced by bacterial colonization and an increased in sialylated mucin content was reported. ${ }^{52}$

According to our histochemical results, no differences were evident in glycoproteins secretion between the small and large intestine. However, the amount of material stained positive with $\mathrm{PAS} / \mathrm{AB}, \mathrm{PAS}, \mathrm{KOH} / \mathrm{PAS}$ and AF/AB in both the small and large intestine were significantly different. The greater number of goblet cells and staining area in large intestine compared with small intestine would suggest the large intestine may be a preferred region for bacterial colonization. HA was a major component of connective tissue matrices, where its function include promoting matrix assembly, viscosity of some fluids and tissue hydration because of its water binding property. ${ }^{53,54}$ Based on this data point, HA acts as a water barrier, and it probably enables the transfer of water towards the epithelial layer of the gastrointestinal system. Therefore, HA and goblet cells work together to maintain tissue moisture, enable the gastrointestinal tract lubrication and reduce mechanical friction. $\mathrm{HA}$ is a fundamental constituent of the interstitial barrier. It provides to decrease tissue permeability, thereby increasing the viscosity of tissue. Catalyzing the hydrolysis of hyaluronic acid by hyaluronidase causes increased tissue permeability. Therefore it is used in medicine in conjunction with other drugs to speed their dispersion and delivery. Some bacteria, such as Staphylococcus aureus, Streptococcus pyogenes and Clostridium perfringens produce hyaluronidase to hydrolyse hyaluronic acid as means of increasing mobility through the body's tissues. ${ }^{55-61}$ Based of these data points, HA with the GPs in goblet cells probably have a function as protection against chemicals and bacteria or other pathogens. Therefore HA was widely localized in submucosa beneath the epithelial layer of the gastrointestinal system to act as chemical and biological defence barrier. It can be concluded that the contents of mucous cell were composed of neutral and acidic GPs; GPs with sialic acids and sulphated GPs. Considering the importance of glycoconjugates and HA, they act significant role including maintain tissue moisture, lubrication with reducing mechanical friction, and protection against chemicals and pathogens.

\section{References}

1. Stevens CE, Hume ID. Comparative physiology of the vertebrate digestive system. Cambridge University Press, Cambridge; 2004.

2. Smith DM, Grasty RC, Theodosiou NA, Tabin CJ, Nascone-Yoder NM. Evolutionary relationships between the amphibian, avian, and mammalian stomachs. Evol Dev 2000;2:348-59.

3. Díaz A0, García AM, Devincenti CV, Goldemberg AL. Morphological and histochemical characterization of the mucosa of the digestive tract in Engraulis anchoita (Hubbs and Marini, 1935). Anat Histol Embryol 2003;32:341-6.

4. Neutra MR, Forstner JF. Gastrointestinal mucus: synthesis, secretion and function, p. 975-1009. In: LR Johnson (ed.), Physiology of the gastrointestinal tract, 2nd ed. Raven Press, New York; 1987.

5 Schumacher U, Duku M, Katoh M, Jörns J, Krause WJ. Histochemical similarities of mucins produced by Brunner's glands and pyloric glands: a comparative study. Anat Rec Part A 2004;278:540-50.

6. Varki A. Biological roles of oligosaccharides: all of theories are correct. Glycobiology 1993;3:97-130.

7. McKee JR, McKee T. Biochemistry: an introduction, 2nd ed. WCB/McGraw Hill, Boston; 1999.

8. Sharon N, Lis H. The structural basis for carbohydrate recognition by lectins. Adv Exp Med Biol 2001;491:1-16.

9. Göransson V. Hyaluronan and renal fluid handling. Studies during normal and pathological conditions of renal function. PhD Thesis, Uppsala University; 2001.

10. Noble PW. Hyaluronan and its catabolic products in tissue injury and repair. Matrix Biol 2002;21:25-9.

11. Toole BP, Wight TN, Tammi MI. Hyaluronan-cell interaction in cancer vascular disease. J Biol Chem 2002;277:4593-6.

12. Turley EA, Noble PW, Bourguignon LYW. Signaling properties of hyaluronan recep- tors. J Biol Chem 2002;277:4589-92.

13. Majors AK, Austin RC, de la Motte CA, Pyeritz RE, Hascall VC, Kessler SP, et al. Endoplasmic reticulum stress induces hyaluronan deposition and leukocyte adhesion. J Biol Chem 2003;278:47223-31.

14. Feder ME. A perspective on environmental physiology of the amphibians, p 1-6. In: ME Feder and WW Burggren (eds.), Environmental physiology of the amphibians. University of Chicago Press, Chicago; 1992.

15. Ishizuya-Oka A, Shuichi U. Apoptosis and cell proliferation in the Xenopus small intestine during metamorphosis. Cell Tissue Res 1996;286:467-76.

16. Kaltenbach JC, Fry AE, Colpitts KM, Faszewski EE. Apoptosis in the digestive tract of herbivorous Rana pipiens larvae and carnivorous Ceratophrys ornata larvae: an immunohistochemical study. J Morphol 2012;273:103-8.

17. Fry AE, Kaltenbach JC. Histology and lectin-binding patterns in the digestive tract of the carnivorous larvae of the anuran, Ceratophrys ornata. J Morphol 1999;241: 19-32.

18. Ishizuya-Oka A, Shimozawa A. Changes in lectin-binding pattern in the digestive tract of Xenopus laevis during metamorphosis. II. small intestine. J Morphol 1990;205:9-15.

19. Lee ER, Leblond CP. Dynamic histology of the antral epithelium in the mouse stomach: IV. Ultrastructural and renewal of gland cells. Am J Anat 1985;172:205-24.

20. Oinuma T, Kawano J, Suganuma T. Bromodeoxyuridine-immunohistochemistry on cellular differentiation and migration in the fundic gland of Xenopus laevis during development. Cell Tissue Res 1992;269:205-12.

21. Nomura S, Esumi H, Job C, Tan SS. Lineage and clonal development of gastric glands. Dev Biol 1998;204:124-35.

22. Ishizuya-Oka A, Shi YB. Molecular mechanisms for thyroid hormone-induced remodeling in the amphibian digestive tract: A model for studying organ regeneration. Dev Growth Differ 2005;47:601-7.

23. AmphibiaWeb, 2014. Information on amphibian biology and conservation [web application]. AmphibiaWeb, Berkeley, CA, USA. Accessed on: 25.10.14. Available from: http://amphibiaweb.org/

24. Yıldırım E, Kaya U. Comparative skeletogenesis of the oriental tree frog Hyla orientalis (Anura: Hylidae). Zool Anz 2014;253:361-71.

25. Baran I, Ilgaz Ç, Avcı A, Kumlutaş Y, Olgun K. [Turkey amphibians and reptiles]. [Book in Turkish]. The scientific and Technological Research Council of Turkey; 
2012.

26. Stöck M, Dubey S, Klütsch C, Litvinchuk SN, Scheidt U, Perrin N. Mitochondrial and nuclear phylogeny of circum Mediterranean tree frogs from the Hyla arborea group. Mol Phylogenet Evol 2008;49:1019-24.

27. Kovács ÉH, Sas I, Covaciu-Marcov SD, Hartel T, Cupsa D, Groza M. Seasonal variation in the diet of a population of Hyla arborea from Romania. Amphibia-Reptilia 2007;28:485-91.

28. Atatür MK, Arıkan H, Çevik IE, Mermer A. Erythrocyte measurements of some scincids from Turkey. Turk J Zool 2001;25:149-52.

29. Naya DE, Bozinovic F. Digestive phenotypic flexibility in post-metamorphic amphibians: Studies on a model organism. Biol Res 2004;37:365-70.

30. Dunel-Erb S, Chevalier C, Laurent P, Bach A, Decrock F, Le Maho Y. Restoration of the jejunal mucosa in rats refed after prolonged fasting. Comp Biochem Physiol A Mol Integr Physiol 2001;129:933-47.

31. Secor SM. Physiological responses to feeding, fasting and estivation for anurans. $\mathrm{J}$ Exp Biol 2005;208:2595-608.

32. Cramp RL, Franklin CE. Arousal and refeeding rapidly restores digestive tract morphology following aestivation in green-striped burrowing frogs. Comp Biochem Physiol A Mol Integr Physiol 2005;142:451-60.

33. Liquori GE, Mastrodonato M, Zizza S, Ferri D. Glycoconjugate histochemistry of the digestive tract of Triturus carnifex (Amphibia, Caudata). J Mol Histol 2007;38:191-9.

34. Liquori GE, Scillitani G, Mastrodonato M, Ferri D. Histochemical investigations on the secretory cells in the oesophagogastric tract of the Eurasian green toad, Bufo viridis. Histochemical J 2002;34:517-24.

35. Lehman S, Smith AA. Regional differentiation in the stomach of the green anole. Anat Rec 1988;220:364-8.

36. Ferri D, Liquori GE. Characterization of secretory cell glycoconjugates in the alimentary tract of the ruin lizard (Podarcis sicula campestris De Betta) by means of lectin histochemistry. Acta Histochem 1992;93:341-9.

37. Çakıcı Ö, Akat E. Some histomorphological and histochemical characteristics of the digestive tract of the snake-eyed lizard, Ophisops elegans Menetries, 1832 (Squamata: Lacertidae). North-West J
Zool 2013;9:257-63.

38. Ferri D, Liquori GE, Natale L, Santarelli G, Scillitani G. Mucin histochemistry of the digestive tract of the red-legged frog Rana aurora aurora. Acta Histochem 2001;103:225-37.

39. Suganuma T, Katsuyama T, Tsukahara M, Tatematsu M, Sakakura Y, Murata F. Comparative histochemical study of alimentary tracts with special reference to the mucous neck cells of the stomach. Am J Anat 1981;161:219-38.

40. Spicer SS, Sun DCH. Carbohydrate histochemistry of gastric epithelium secretions in dog. Ann N Y Acad Sci 1967;140:762-783.

41. Domeneghini C, Arrighi S, Radaelli G, Bosia G, Veggetti A. Histochemical analysis of glycoconjugate secretion in the alimentary canal of Anguilla anguilla L. Acta Histochem 2005;106:477-87.

42. Leiv Leknes I. Histochemical studies on mucin-rich cells in the digestive tract of a teleost, the Buenos Aires tetra (Hyphessobrycon anisitsi). Acta Histochem 2011;113:353-7.

43. Domeneghini C, Pannelli Straini R, Veggetti A. Gut glycoconjugates in Sparus aurata L. (Pisces, Teleostei). A comparative histochemical study in larval and adult ages. Histol Histopathol 1998;13:359-72.

44. Veggetti A, Rowlerson A, Radaelli G, Arrighi S, Domeneghini C. Post-hatching development of the gut and lateral muscle in the sole. J Fish Biol 1999;55:44-65.

45. Pedini V, Scocco P, Radaelli G, Fagioli 0, Ceccarelli P. Carbohydrate histochemistry of the alimentary canal of the shi drum, Umbrina cirrosa L. Anat Histol Embryol 2001;30:345-9.

46. Díaz A0, García AM, Goldemberg AL. Glycoconjugates in the mucosa of the digestive tract of Cynoscion guatucupa: A histochemical study. Acta Histochem 2008;110:76-85.

47. Carrassón M, Grau A, Dopazo LR, Crespo S. A histological, histochemical and ultrastructural study of the digestive tract of Dentex dentex (Pisces, Sparidae). Histol Histopathol 2006;21:579-93.

48. Cinar K, Şenol N. Histological and histochemical characterization of the mucosa of the digestive tract in flower fish (Pseudophoxinus antalyae). Anat Histol Embryol 2006;35:147-51.

49. Murray HM, Wright GM, Goff GP. A comparative histological and histochemical study of the post-gastric alimentary canal from three species of pleuronectid, the Atlantic halibut, the yellowtail flounder and winter flounder. J Fish Biol 1996;48:187-206.

50. Tibbetts IR. The distribution and function of mucous cells and their secretions in the alimentary tract of Arrhamphus sclerolepis krefftii. J Fish Biol 1997;50:809-20.

51. Zimmer G, Reuter G, Schauer R. Use of influenza $\mathrm{C}$ virus for detection of 9-0acetylated sialic acids on immobilized glycoconjugates by esterase activity. Eur J Biochem 1992;204:209-15.

52. Forder REA, Howarth GS, Tivey DR, Hughes RJ. Bacterial modulation of small intestinal goblet cells and mucin composition during early posthatch development of poultry. Poult. Sci 2007;86:2396-403.

53. Elkan E. Mucopolysaccharides in the anuran defence against desiccation. J Zool 1968;155:19-53.

54. Laurent TC, Laurent UBG, Fraser JRE. The structure and function of hyaluronan: an overview. Immunol Cell Biol 1996;74:A1-A7.

55. Ponnuraj K, Jedrzejas MJ. Mechanism of hyaluronan binding and degradation: Structure of Streptococcus pneumoniae hyaluronate lyase in complex with hyaluronic acid disaccharide at $1.7 \AA$ A resolution. J Mol Biol 2000;299:885-95.

56. Lin G, Stern R. Plasma hyaluronidase (Hyal-1) promotes tumor cell cycling. Cancer Lett 2001;163:95-101.

57. Lokeshwar VB, Schroeder GL, Carey RI, Soloway MS, Iida N. Regulation of hyaluronidase activity by alternative mRNA splicing. J Biol Chem 2002;277: 33654-63.

58. El Hajjaji H, Cole AA, Manicourt DH. Chondrocytes, synoviocytes and dermal fibroblasts all express $\mathrm{PH}-20$, a hyaluronidase active at neutral $\mathrm{pH}$. Arthritis Res Ther 2005;7:756-68.

59. Kim E, Baba D, Kimura M, Yamashita M, Kashiwabara SI, Baba T. Identification of a hyaluronidase, Hyal5, involved in penetration of mouse sperm through cumulus mass. P Natl Acad Sci USA 2005;102: 18028-33.

60. Girish KS, Kemparaju K. Inhibition of Naja naja venom hyaluronidase: Role in the management of poisonous bite. Life Sci 2006;78:1433-40.

61. Necas J, Bartosikova L, Brauner P, Kolar J. Hyaluronic acid (hyaluronan): a review. Vet Med-Czech 2008;53:397-411. 